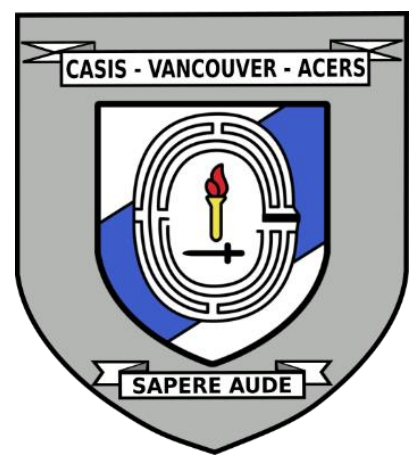

\title{
EXTREMISM AND COVID-19
}

Date: April 18, 2020

Disclaimer: This briefing note contains summaries of open sources and does not represent the views of the Canadian Association for Security and Intelligence Studies.

\section{PURPOSE STATEMENT}

The purpose of this briefing note is to examine security threats posed by Rightwing and Islamist Extremist groups in light of the COVID-19 pandemic. This briefing note will also connect extremist actions to Violent Transnational Social Movement (VTSM) theory. For further information on VTSM theory, please visit the Canadian Centre for Identity-Based Conflict.

\section{SECURITY PROBLEM}

The COVID-19 pandemic has provided extremist groups with many new opportunities to threaten Canadians and Canadian security. The virus' potential to be used as a bioweapon, the targeting of Asian minorities with hate crimes, and extremists' use of the lockdown to recruit and garner support are all problematic. If acted upon, extremist intentions during the COVID-19 outbreak could cause further spread of the virus and result in increased hospitalizations or deaths, an increased strain on government resources, or even societal breakdown. It is even possible that individuals who are otherwise unaffiliated with extremist groups may be more vulnerable to radicalization due to the potential psychological effects of the crisis. The strategies discussed are not necessarily specific to individual groups but shared across the facets of each VTSM via online platforms.

\section{KEY FACTS}

It can be argued that online propaganda can be used by extremist groups to spin the pandemic in their favour, incite hate, recruit new members and call to action those that support their cause. It should be noted that "terrorist groups are blasting online propaganda messages toward followers and potential recruits which hail the calamity of the disease as divine retribution" (Meek, 2020, para. 1). According to the Counterterrorism Mission Center and Countering Weapons of Mass Destruction Office, "violent extremists probably are seeking to exploit 
public fears associated with the spread of COVID-19 to incite violence, intimidate targets and promote their ideologies, and we assess these efforts will intensify in the coming months" (Meek, 2020, para. 19).

Right-wing Extremist (RWE) groups in Canada and abroad have discussed using COVID-19 as a bioweapon against law enforcement and minorities, placing these groups at higher risk (U.S. Department of Homeland Security, 2020). These groups have stated that it is an obligation by them to spread the virus should any member or supporter contract the virus and become contagious (U.S. Department of Homeland Security, 2020).

According to the U.S. Department of Homeland Security, some of the methods discussed by extremists to spread COVID-19 on specific target groups include:

[Spending] as much time as possible in public spaces with their 'enemies,' [visiting] local FBI offices and [leaving] saliva on door handles, [spraying] saliva from spray bottles on the faces of law enforcement, [committing] crimes ... and [leaving] COVID-19 laced items at the scene for detectives to find, [spitting] on elevator buttons, [and spreading] COVID-19 in non-white neighborhoods. (2020, p. 1)

Individuals have posted on online platforms stating they have carried out actions such as "coughing in a rabbi's face and wiping mucus on the gas pumps...[at] every Indian-owned gas station..." (Green, 2020, para. 2). It is worth noting that in response to such potential actions, the "US Deputy Attorney General Jeffrey Rosen wrote in a memo that anyone who deliberately spreads coronavirus could be charged under antiterrorism laws because the virus appears to meet the statutory definition of a 'biological agent'”' (Grewal, 2020, para. 16).

Extremist actors may also see hospitals and care centres as new targets of opportunity because of the virus. Seen in the events of recently deceased rightwing figure Timothy Wilson who, "had been planning to attack a hospital caring for patients suffering from COVID-19," such violent actions may also incite further violence elsewhere (Colborne, 2020, para. 30).

Acts of violence and hate speech towards Asian communities in particular have seen a marked increase during the pandemic (Werleman, 2020). The virus originated in China, and RWE groups and individuals have used this as justification for targeting people of many Asian backgrounds (Breaking 911, 2020; Werleman, 2020). It is possible that RWE actors may use similar rationale

The Journal of Intelligence, Conflict, and Warfare Volume 3, Issue 1 
to justify hate crimes against other minority and immigrant groups (Grewal, 2020).

Some RWE actors adhere to a belief that the best way to enact the changes in society that they want is to overwhelm and topple the existing societal structure (Khalil \& Roose, 2020). Certain groups who are present in Canada and the United States, such as The Base and Atomwaffen, have already discussed using the quarantine as an opportunity to start a race war which would threaten national security during the pandemic and bring about the societal collapse they seek (McCarten, 2020).

\section{BACKGROUND}

Extremist groups have used online networks for some time to share ideas amongst themselves, develop their theories, recruit individuals and spread propaganda across online spaces (McCarten, 2020). It can be suggested that RWE groups function as segments of a VTSM, where messages can jump between groups and geographical regions with relative ease as part of a larger phenomenon (Kelshall, 2018). This was seen earlier in the year when "far-right extremists in Australia spread the conspiracy, through various social media channels, that the bushfires were started by Muslims who committed 'arson' or 'bushfire' jihad. This narrative was quickly picked up by US far-right and altright groups and spread globally" (Khalil \& Roose, 2020, para. 7). Sources are often easily accessible and anonymous, thus creating more work for law enforcement and allowing unassociated individuals the ability to radicalize without the direct coordination of formal group leadership. VTSM theory posits that these groups are segmentary, reticulate and polycentric in nature; these are the traits that are arguably being showcased through recently observed extremist actions (Kelshall, 2018).

The idea of starting a race war is not new to RWE groups, as many consider it the most efficient way to topple the current social status quo and instill their own version of what society should look like (McCarten, 2020). These particular RWE actors are often referred to as accelerationists due to their desire to accelerate societal collapse, something they see as inevitable (Haze, 2020). Patrik Mathews, a member of The Base, attended a gun rights rally in Virginia and was recorded stating that "all you gotta do is start making things go wrong and [...] Virginia can spiral out to (expletive) full-blown civil war" (McCarten, 2020, para. 13). Following the accelerationist model, "neoNazi accelerationist 
Telegram channels have increased their calls for destabilisation and violence" in relation to the COVID-19 pandemic (Colborne, 2020, para. 16).

\section{KEY CONSIDERATIONS AND IMPLICATIONS}

Feelings of loneliness and boredom associated with the COVID-19 quarantine may result in more individuals gravitating towards charismatic individuals and extremist ideologies as they seek a sense of purpose and belonging (Malik, 2020). Additionally, the longer the pandemic continues the more likely it is that individuals will gravitate towards extremism, as uncertainty, unemployment and isolation increase negative emotions and feelings of desperation (Werleman, 2020).

Some communities, such as the Asian community, may come under greater threat as groups associate them with the origin of the virus and attach blame. For example, "three Asian American family members, including a 2-year-old and 6year-old were stabbed because the suspect 'thought the family was Chinese, and infecting people with the coronavirus,"' according to an excerpt from an FBI analysis dated March 13 th, 2020 (as cited in Werleman, 2020, para. 12).

Political officials and governments may also be targeted as evidenced in some Islamist extremist discourse: "New York-based political activist Bahgat Saber calmly and rationally called on Egyptians who have contracted coronavirus to exact revenge by intentionally infecting state officials and government employees" (Malik, 2020, para. 8).

\section{WHAT IS NOT KNOWN}

It is not known whether actions have been taken by extremist groups or individuals to further the spread of the COVID-19 virus.

It is not known to what extent the social and psychological effects of social distancing and financial uncertainty will bolster extremist messaging and calls to action.

The duration of the COVID-19 crisis is at this time unknown, as are the longterm effects and responses by extremist groups. 


\section{NEXT STEPS}

- Security services and law enforcement should remain vigilant to a plausible increase in extremist activity during and following the COVID-19 crisis.

- Social media platforms can work to shut down misinformation and the spread of extremist rhetoric in their online networks

- Monitoring of forums frequented by RWE groups may inform law enforcement of where potential threats may occur.

- Linguistic analysis may reveal when individuals participating in online forums are on the path to, or about to undertake, violent actions of extremist nature.

The Journal of Intelligence, Conflict, and Warfare Volume 3, Issue 1 


\section{References}

Breaking 911. (2020, March 25). WA state police chief says asian-americans are being targeted due to COVID-19 but aren't being reported. Retrieved from https://breaking911.com/wa-state-police-chief-saysasian-americans-arebeing-targeted-due-to-covid-19-but-arent-beingreported/

Canadian Centre for Identity Based Conflict. (2020, February 14). White supremacist flyers in Vancouver. Retrieved from http://vtsm.org/2020/02/14/flash-cardwhite-supremacist-recruitmentflyers-in-vancouver/

Colborne, M. (2020, March 26). As world struggles to stop deaths, far right celebrates COVID-19. Aljazeera. Retrieved from https://www.aljazeera.com/indepth/features/world-struggles-stopdeathscelebrates-covid-19200326165545387.html?fbclid=IwAR3C_g_9ldukXQEuSCsHlT96Gv MjbOZ v2ZPXjROIsEC9Vz13UxrTkD_AaUU

Green, J. (2020, March 24). Gleeful neo-Nazis see echoes of the 1930s as America plunges into a coronavirus crisis. Raw Story. Retrieved from https://www.rawstory.com/2020/03/gleeful-neo-nazis-see-echoes-ofthe-1930s-as-america-plunges-into-a-coronavirus-crisis/

Grewal, K. (2020, March 28). 'Excuse to destroy our people': Far right groups weaponise coronavirus to further their agenda. The Print. Retrieved from https://theprint.in/world/excuse-to-destroy-our-people-far-rightgroupsweaponise-coronavirus-to-further-their-agenda/390244/

Haze, M. (2020, March 22). White supremacists spoke of weaponizing COVID-19 to attack police and minorities. Discuss Global. Retrieved from https://discussglobal.com/white-supremacists-weaponizing-covid19-attackpolice/

Kelshall, C. M. (2018). Chapter 2: Violent transnational social movements. In C. M. Kelshall \& V. Dittmar (Eds.), Accidental Power: How non-state actors hijacked legitimacy and re-shaped the international system (pp. 24-39). Burnaby, BC: Simon Fraser University Library.

The Journal of Intelligence, Conflict, and Warfare Volume 3, Issue 1 
Khalil, L., \& J. M. Roose. (2020, March 19). Countering extremism in the midst of coronavirus. The Interpreter. Retrieved from https://www.lowyinstitute.org/the-interpreter/countering-extremismmidstcoronavirus

Malik, N. (2020, March 26). Self-isolation might stop coronavirus, but it will speed the spread of extremism. Foreign Policy. Retrieved from https://foreignpolicy.com/2020/03/26/self-isolation-might-stopcoronavirusbut-spread-extremism/

McCarten, J. (2020, February 18). 'This is the age of war': alleged Canadian neoNazi pleads not guilty to weapons charges. The National Post. Retrieved from https://nationalpost.com/news/patrik-mathews-accusedneo-nazi-to-appear-incourt-in-maryland

Meek, J. (2020, April 2). Terrorist groups spin COVID-19 as God's 'smallest soldier' attacking west. ABC News. Retrieved from https://abcnews.go.com/International/terrorist-groups-spin-covid-19godssmallest-soldier/story?id=69930563

U.S. Department of Homeland Security. (2020, February 17). Federal protective service: weekly intelligence brief. Scribd. Retrieved from https://www.scribd.com/document/452676693/White-SupremacistCorona\#fullscreen\&from_embed

Werleman, C. (2020, April 2). The coronavirus pandemic is a rallying cry for far-right bigots. TRT World. Retrieved from https://www.trtworld.com/opinion/the-coronavirus-pandemic-is-arallyingcry-for-far-right-bigots-35053 


\section{(c) $(1) \Theta \Theta$}

CY NC ND This work is licensed under a Creative Commons Attribution-

NonCommercial-NoDerivatives 4.0 International License.

(C) (CASIS-VANCOUVER, 2020)

Published by the Journal of Intelligence, Conflict, and Warfare and Simon Fraser University

Available from: https://jicw.org/ 